AUTHENTIC WINE 
This page intentionally left blank 


\section{AUTHENTIC WINE}

Toward Natural and Sustainable Winemaking

Jamie Goode and Sam Harrop, MW

무

UNIVERSITY OF CALIFORNIA PRESS

Berkeley LosAngeles London 
University of California Press, one of the most distinguished university presses in the United States, enriches lives around the world by advancing scholarship in the humanities, social sciences, and natural sciences. Its activities are supported by the UC Press Foundation and by philanthropic contributions from individuals and institutions. For more information, visit www.ucpress.edu.

University of California Press

Berkeley and Los Angeles, California

University of California Press, Ltd.

London,E ngland

(C) 2011 by The Regents of the University of California

Library of Congress Cataloging-in-Publication Data

Goode, Jamie.

Authentic wine : toward natural and sustainable winemaking / Jamie Goode and Sam Harrop. p.c m.

Includes index.

ISBN 978-0-520-26563-9 (cloth : alk. paper)

1. Wine and wine making. 2. Organic wines. 3. Organic viticulture. I. Harrop, Sam. II. Title.

TP548.G6259 2011

641.2 '2-dc22

2010052392

Manufactured in the United States of America

$\begin{array}{lllllllll}19 & 18 & 17 & 16 & 15 & 14 & 13 & 12 & 11\end{array}$

$\begin{array}{llllllllll}10 & 9 & 8 & 7 & 6 & 5 & 4 & 3 & 2 & 1\end{array}$

In keeping with a commitment to support environmentally responsible and sustainable printing practices, UC Press has printed this book on Rolland Enviro100, a 100\% post-consumer fiber paper that is FSC certified, deinked, processed chlorine-free, and manufactured with renewable biogas energy. It is acid-free and EcoLogo certified. $\infty$

Jacket design and illustration by Claudia Smelser.

Note: All the photographs in this book were taken by Jamie Goode. 